\title{
Hur arbetsmarknadssystemet utestänger de funktionshindrade
}

\author{
DIMITRIS MICHAILAKIS
}

I artikeln hävdas att uppkomsten av begreppet handikapp kan relateras till uppkomsten av ett särskilt arbetsmarknadssystem. Arbetsmarknadens krav varierar, och de är historiskt bestämda. Gruppen funktionshindrade har inte alltid bedömts som arbetsoförmögen. Distinktionen arbetsförmögen/arbetsoförmögen uppstod, när arbetsmarknaden särskiljdes ur det ekonomiska systemet och blev ett eget system, med egen kod och kommunikationsmedium. Som ett autopoietiskt system i ett från funktionssynpunkt differentierat samhälle, fungerar arbetsmarknadssystemet enligt principen om självreferens och självobservation. Utifrain sina selektionskriterier exkluderar det alla aspekter som inte kan relateras till individens förmåga eller oförmåga att arbeta.

\section{Uppkomsten av kategorin handikapp}

De funktionshindrade har kommit in på arbetsmarknaden under perioder, när deras funktionshinder inte definierats som arbetsoförmåga (arbetshandikapp) eller när deras arbetsoförmåga har kunnat kompenseras med andra medel. De krav som ligger under

Dimitris Michailakis är docent i sociologi vid Högskolan i Gävle. uppdelningen i arbetsförmögna och arbetsoförmögna varierar över tiden. När kraven på arbetskraften ökar, till exempel genom rationaliseringar i produktionen, ökar antalet arbetsoförmögna. Allmänt kan vi säga att utbud och efterfrågan på arbetskraft direkt kan relateras till hur begreppen arbetsförmåga och arbetsoförmåga definieras. Ökad efterfrågan på arbetskraft leder till att fler kommer in på arbetsmarknaden. En strängare tolkning av arbetsförmåga leder till att utbudet av arbetskraft minskar, eller 
att färre registreras som arbetssökande. På dagens arbetsmarknad ser vi en tendens till ökade krav på dem som anställs. En allt större del av arbetskraften anses inte motsvara produktionens krav. Det ökade antalet förtidspensioneringar ger en indikation på de uppskruvade kraven på arbetsförmåga (Stattin 1998).

I en historisk genomgång av socialförsäkringssystemet i USA, Holland, Tyskland och Sverige visar Stone (1985) en förbindelse mellan den ekonomiska situationen, främst arbetslöshetstalen, och förtidspensionering på grund av arbetsoförmåga. Stone anser att "förmånen" att bli förklarad arbetsoförmögen uppvägs av den hårdhet med vilken man behandlar alla dem som officiellt inte kategoriseras som arbetsoförmögna, men som ändå inte klarar av att på egen hand uppnå en anständig levnadsnivå, t.ex. arbetslösa, låginkomsttagare, deltidsarbetande och ensamstående föräldrar. Definitionen av kategorin arbetsoförmåga underförstår vad som förväntas av de arbetsförmögna, vilka skador, sjukdomar och problem man förväntas acceptera.

Stone hävdar att begreppet handikapp har omdefinierats i välfärdssamhällena. Det har vidgats från en snäv medicinsk definition till att bli ett bredare begrepp knutet till den arbetandes förmåga att tjäna ihop till sitt uppehälle. Det framgår tydligt, inte minst i Stones egen studie, att arbetsoförmåga snarare är en socialt konstruerad kategori än en egenskap som kan tillskrivas individer. Mot Stones analys kan dock invändas att även det hon kallar snäv medicinsk definition är en social konstruktion (jfr Foucault 1975).

Stonehävdaratt kapitalismens utveckling har åtföljts av förstärkta rationaliseringsoch byråkratiseringsprocesser. I dessa spelar konstruktionen av handikapp en nyckelroll. Enligt Stone återfinns i alla samhällen ett komplext system av varuproduktion och distribution. Det huvudsakliga medlet för att fördela resurserna är arbete. Eftersom inte alla är förmögna eller villiga att arbeta, uppstår dock ett distributivt problem. Frågan blir hur resurserna skall fördelas på basis av två skilda principer: arbete och behov. Dilemmat löses genom att begreppet handikapp utvecklas till en gränskategori, som hänför människorna till antingen det arbetsbaserade eller det behovsbaserade systemet. Stone anser alltså att den sociala konstruktionen av handikapp är ett resultat av statens behov att kontrollera tillgången till det statsfinansierade välfärdssystemet. Därmed samlas ofrånkomligen makt hos de yrkesgrupper som har ansvar för resursfördelningen: läkare och jurister.

Stones analys hör till de mer seriösa försöken att förklara hur kategorin handikapp har uppkommit. Hennes analys lider dock av den aktörsorienterade analysens problem; Weber utgör en tydlig inspirationskälla för hennes arbete. Enligt hennes teori skapas i sista hand kategorin handikapp genom statens medvetna försök att med hjälp av juridisk och medicinsk expertis lösa frågan hur samhällets resurser skall fördelas.

I det följande försöker jag förklara uppkomsten av kategorin handikapp utifrån Luhmanns sociologiska systemteori. Min tes är att arbetsmarknaden blev ett autopoietiskt system, när den särskiljdes från det ekonomiska systemet. Därigenom skapades också distinktionen arbetsförmåga/ arbetsoförmåga. Dessa kategorier utgör sys- 
temets gränser mot omvärlden. De bestämmer vem som skall inkluderas i systemet, och vem som skall exkluderas från det. Gränsen mellan arbetsförmåga och arbetsoförmåga är något som varje samhälle måste konstruera och rekonstruera, när de sociala förhållandena förändras.

Arbetsförmåga eller arbetsoförmåga är inte egenskaper hos individer. Det är systemet som definierar vad de är. Även en ickefunktionshindrad personkan av arbetsmarknadssystemet förklaras som arbetsoförmögen, på grund av t.ex. bristande utbildning eller bristande färdigheter. Omvänt kan en person med grava funktionshinder bli arbetsförmögen inom ett visst arbete, t.ex. med hjälp av särskilda redskap. Likväl klassas många som handikappade på grund av fysiska, psykiska eller intellektuella brister, samtidigt som individualiseringen trissar upp de fysiska, psykiska och intellektuella kraven på dem som inkluderas i systemet.

I en situation där ideologin föreskriver att alla skall arbeta, men där en stor del av befolkningen inte omfattas av arbetsmarknadssystemet, kan dilemmat lösas genom att fler definieras som arbetsoförmögna eller arbetshandikappade. Ett utvidgat handikappbegrepp reducerar trycket av arbetslösa på systemet, samtidigt som det vidmakthåller arbetsideologins legitimitet.

\section{Effekterna av funktionell differentiering}

Om segmentering eller stratifiering var den huvudsakliga struktureringsprincipen $\mathrm{i}$ äldre samhällen, karaktäriseras enligt Luhmann (1995) det moderna samhället av motsatsen, alltså av en funktionell differentie- ring. Som ett resultat av den ökade sociala komplexiteten uppstod i övergången från den feodala ordningen nya funktionssystem, alla med högre grad av autonomi. Dessa funktionssystem utgör det moderna samhällets grundläggande enheter. Det moderna samhället är alltså inte strukturerat som ett hierarkiskt klassamhälle, utan differentierat i olika funktionssystem, t.ex. politik, juridik, ekonomi, utbildning, konst och religion. Isystemen sker dessutom en intern differentiering. Funktionssystemet ekonomi inrymmer således banksystem, produktionssystem och flera andra organisationssystem.

Intern differentiering uppstår också som en effekt av ökad komplexitet. Men systemen kan inte bli hur komplexa som helst. Då riskerar de att bli dysfunktionella. De måste specialiseras, för att en alltmer komplex omvärld skall kunna hanteras. Det sker genom att väl avgränsade funktioner övertas. En annars ohanterlig komplexitet i fråga om t.ex. ekonomiska transaktioner, maktrelationer, tvister, frågor om kunskap eller avtal om arbetskraft kan därigenom reduceras. Så kan samhället fortleva, utan att en genomgripande samhällelig enighet måste skapas (Jönhill 1997).

Precis som en levande organism behöver alla sina biologiska funktioner för att överleva, behövs varje funktion för att i sin helhet hålla det sociala systemet vid liv (Willke 1997). Tesen att samhället kan rangordna sina delar håller därför inte; det är inte underkastat ett enskilt funktionssystem. En förutsättning för att samhället skall styras utifrån ett visst system, är att detta systems kommunikationsmediumkan tränga igenom i samhället som helhet. Men varken ekonomin, politiken eller juridiken har sådana 
generella kommunikationsmedier. Om det inte är möjligt att behandla utbildning, ekonomi, juridik, vetenskap eller något annat system som viktigare än andra, finns det inget utrymme för en hierarkisk modell.

Den funktionella differentieringen tvingar därtill en observatör att betrakta varje fråga utifrån ett visst system. Enligt Luhmann kan man inte inta en privilegierad position, från vilken samhället kan överblickas i sin helhet. Inte heller kan man observera ett fenomen från flera olika positioner samtidigt. Allt som betraktas från ett visst system, kan även betraktas från ett annat system och beskrivas eller tolkas på ett annat sätt utifrån den alternativa utgångspunkten. Det finns alltså inget privilegierat perspektiv, ingen utsiktspunkt från vilken vi kan observera allting.

Funktionshindradepersonersuteslutning från arbetsmarknaden kan inte studeras utifrån ett övergripande perspektiv, eftersom samhället består av flera olika subsystem som kommunicerar temat "personer med funktionshinder i arbetslivet» från skilda utgångspunkter. Vad som i ett system iakttas och beskrivs som arbetsoförmåga, kan $\mathrm{i}$ ett annat system beskrivas som något helt annat. Vadarbetsmarknadssystemet utifrån en där nödvändig kalkyl av kostnadsförhållandet mellan lön och arbetsresultat kan se som arbetsoförmåga, kan i det rättsliga systemet tolkas som en skillnad mellan olika gruppers rättskapacitet. I rehabiliteringssystemet kan samma förhållande definieras som en funktionsnedsättning. Funktionshindrade personers uteslutning från arbetsmarknaden i ett funktionellt differentierat samhälle är därmed inte ett för hela samhället gemensamt problem. De funktionshin- drades uteslutning väcker olika frågor beroende på det perspektiv som observatören intar. Detta beror i sin tur på från vilket system han observerar fenomenet.

Utifrån sina skilda funktioner kommunicerar olika system temat på olika sätt. Systemen har skilda uppgifter. De iakttar, beskriver och kommunicerar temat utifrån den funktion de fyller. Utifrån vissa system kan funktionshindrade personers uteslutning från arbetsmarknaden utgöra ett problem, t.ex. politiken. För andra system är det inte något problem, t.ex. utbildningssystemet. Uteslutningen angår vissa system, och det angår dem på olika sätt. Sjukvårdssystemet definierar t.ex. frågan som ett medicinskt problem. En enhetlig beskrivning av funktionshindrade personers uteslutning från samhället kan därför inte ges utifrån arbetsmarknadens, rehabiliteringens eller politikens begreppsbildningar.

Samhällets funktionella differentiering omöjliggör även en entydig inplacering av den enskilda individen. Med en mer omfattande funktionell differentiering kan personen inte längre inkluderas endast $i$ ett av samhällets system. Som individer tillhör vi flera system samtidigt. Vi måste föreställa oss en lösare form av bindning till skilda sociala system (Jönhill 1997). Att många funktionshindrade går in på arbetsmarknaden och sedan (efter kortare eller längre tid) ut därifrån, är ett exempel på deras lösa bindning till detta system.

Skillnaden mellan inkludering och exkludering är den mellan personer som är rinne i systemetı och dem som är sutanförr.

Det betyder, som Luhmann uttrycker det, att vissa människor blir personer (de som är sinne i systemetı), medan vissa 
endast blir individer: de som är sutanför systemet،. Icke-tillhörigheten (exkludering/ uteslutning) kan vara självvald. Den kan också vara ett resultat av att den enskilde tvingats stå utanför systemet. En person kan välja att ingå i funktionssystem, som t.ex. religion, vetenskap, konst och ekonomi. När människan får specifika rättigheter/ skyldigheter, ingår hon som person i funktionssystemet "juridik". Inkludering i ett funktionssystem betyder inte automatiskt inkludering i ett annat. Att man i de moderna välfärdssamhällena med juridikens hjälp lyckats eliminera vissa skillnader mellan funktionshindrade personer och icke-funktionshindrade i fråga om sociala, politiska och ekonomiska rättigheter, innebär inte att funktionshindrade personers därmed inkluderats även i andra system, t.ex. arbetsmarknaden (Bausch 1997).

Den funktionella differentieringen gör att det moderna samhället saknar ett centrum, som kan ta hand om förbindelserna mellan funktionssystemen. Samhället har inga övergripande mål, som kan erbjuda riktlinjer för hur man skall behandla dessa frågor; det är en illusion skapad och närd av handlingsteorierna att politiken skulle utgöra ett sådant multifunktionellt centrum. Varje system koncentrerar sig på sin egen funktion. Det definierar sina gränser mot omvärlden och reglerar följaktligen även vad som skall räknas som omvärld från systemets synpunkt. Utan ett sådant centrum, eller en sådan topp, är det moderna samhället horisontellt differentierat (Albertsen \& Diken 2000). I ett sådant system kan inte hierarkiska distinktioner som klass eller sociala skikt tillämpas. Ur systemperspektivet måste frågan om ojämlikhet och exploa- tering omformuleras till en fråga om inkludering i eller exkludering ur skilda funktionssystem.

\section{Funktionssystem som autopoietiska system}

Autopoiesis-teorin (autopoiesis = självproduktion) avser att förklara hur levande system, till skillnad från icke-levande system, fungerar. Enligt Luhmann kan det moderna samhällets funktionella system förstås som autopoietiska system. Teorin om autopoiesis, som har sin grund i biologin, tillhör en tradition av General Systems Theory. Enligt autopoiesis-teorin genomgår alla levande system en kontinuerlig process av intern själv-produktion, medan ickelevande system (allo-poietiska = av andra producerade) producerar något annat än sina egna beståndsdelar.

En av Luhmanns utgångspunkter är att autopoiesis, när den definieras abstrakt, karaktäriserar olika typer av system. Han skiljer mellan organiska (biotiska), psykiska och sociala system. Luhmanns sociologiska systemteori försöker beskriva de grundläggande egenskaper som är gemensamma för de sociala systemen. Han anser att alla sociala system har likartade strukturer och att alla verkar kommunikativt. Därför omdefinierar han de sociala systemen till kommunikationssystem (Lee 2000, Vanderstraeten 2000). I en sådan definition blir kommunikation det enda genuint sociala fenomenet.

Samhället består varken av människor, medvetandetillstånd, roller eller handlingar, utan av skilda slag av kommunikation.

Dessa kommunikationssystem är autopoietiska, därför att kommunikation endast 


\section{Figur I}

Figuren försöker åskådliggöra olika former av autopoietisk organisation

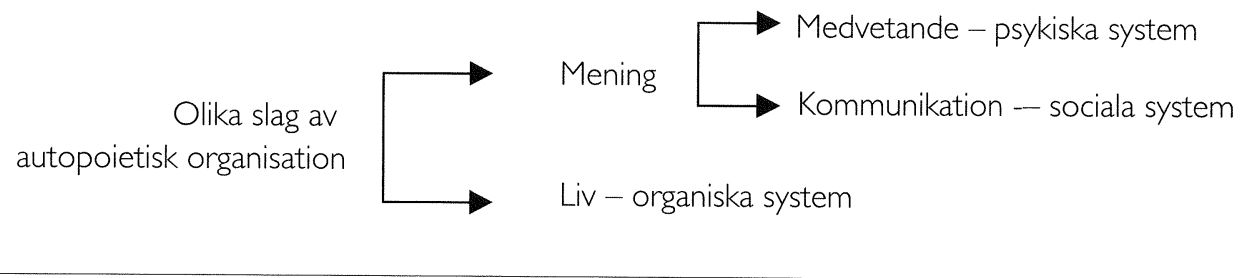

kan identifieras som sådan genom referens till andra typer av kommunikation. Den uppstår alltid i en kontext av annan kommunikation. Sociala system består med andra ord av olika slag av kommunikation. Utifrån systemets funktionella orientering, och i enlighet med selektionskriterier, enligt en binär kod, selekteras och förmedlas kommunikation från omvärlden inom systemet; på liknande sätt som i språkets ja- och nejversion (Luhmann 1995).

Luhmanns angreppssätt är radikalt i den bemärkelsen att det uteslutande betraktar sociala system i kommunikativa termer. Det förpassar därmed individen till de sociala systemens omvärld. Distinktionen mellan system och omvärld innebär dock inte någon normativ värdering. Både system och omvärld är beroende av varandra; de är vad de är endast i en ömsesidig relation. Men genom att vidhålla att både människor och materiella förhållanden måste förstås som delar av den samhälleliga omvärlden, snarare än som delar av funktionssystemen, vill Luhmann påvisa den betydande autonomi som sociala system har, både i förhållande till den materiella världen och utifrån individers intressen, behov och avsikter (Blühdorn 2000).
Till skillnad från Parsons systemteori, överskrider autopoiesisteorin den klassiska dikotominsubjekt/objekt genomattbetrakta kommunikation, inte handling, som det grundläggande elementet $\mathrm{i}$ sociala system. Detta är kanske den mest radikala, och provokativa, idé som Luhmann införlivat med teorin om autopoiesis. Endast via kommunikation kan vi närma oss, eller förstå, samhället.

Kommunikationen i det moderna samhället organiseras inom funktionellt differentierade system (King \& Schütz 1994).

Därför kommunicerar vi alltid inifrån vissa system.

Luhmann hävdar att de sociala systemens logik utvecklas ur deras egna funktionssätt. Sociala system konstruerar sig själva, medan de kommunicerar. De existerar som historiska och aktuella relationer mellan ting. Systemen har ingen natur, bara historia (Lee 2000). Funktionellt differentierade system arbetar med binära koder, binära värden, t.ex. betalning/icke-betalning i det ekonomiska systemet och makt/avsaknad av makt i det politiska systemet. Ett funktionssystems binära kod är också ett medel för att skapa en operativ slutenhet gentemot omvärlden. Genom den binära koden försö- 
ker varje system "förståu omvärlden, genom den reduceras också dess komplexitet. Följaktligen kan ett system bara fungera inom sig självt; kommunikation sker bara inom systemet. Dessa koder aktualiseras för att funktionssystemen skall "förståı omvärlden, men systemen konstrueras även genom koderna: i kommunikation som har selekterats och upprepats i otaliga sammanhang. En kodbådekonstituerarsystemet och bestämmer vad det kan, eller inte kan, inkludera från omvärlden. Systemet är indifferent till allt som dess binära kod exkluderar.

Sociala system är alltså kommunikationssystem som har utvecklats genom en selektionsprocess bland historiskt tillgängliga alternativ (King\& Schütz 1994). Vikan t.ex. se hur gruppen funktionshindrade särskiljdes från kategorin fattiga, dvs. från alla dem utan betalningsförmåga som levde utanför det ekonomiska systemet. Den kategorin inrymde alla som exkluderats, från kriminella, vagabonder och prostituerade till blinda, döva och psykiskt sjuka. Det är den här artikelns tes att de handikappade särskiljdes parallellt med att arbetsmarknadssystemet differentierades som ett autonomt system. Historiskt markeras arbetsmarknadssystemets uppkomst genom distinktionen i kategorin ,fattigar mellan dem som äger arbetsförmåga och dem som saknar sådan.

Definitionsmässigt är ett autopoietiskt system ett system som permanent reproducerar både sin egen struktur och sina egna element. För sociala system betyder det främst att det ständigt försiggår kommunikation och att dess förutsättningar hela tiden reproduceras. Varje autopoietiskt system kan beskrivas i termer av ett tillvägagångssätt eller ett språk som möjliggör att det kan fungera internt. Således arbetar t.ex. det rättsliga systemet med en specifik uppsättning av operationer, som förutsätter ett särskilt språk. Att varje system använder sig av ett särskilt språk för att kommunicera om omvärlden, gör att vi kan tala om system som "stängdau eller operativt slutna. Sociala system är öppna för information. De påverkas av förändringar omvärlden, men de är stängda såtillvida att alla förändringar med nödvändighetär förändringar iderasinterna struktur och inget annat. Alla system är organisatoriskt stängda. De utgör sammanhållna och självproducerande enheter, som fungerar självreferentiellt i enlighet med sin interna logik. Det för systemet särpräglade språket (t.ex. juridikens språk eller religionens språk) gör att information från omvärlden inne i systemet kommuniceras på ett specifikt sätt. Till följd av denna slutenhet, är det inte möjligt att tala om vad som är nyttigt för hela samhället eller vad som vore rationellt för samhället i dess helhet. Samarbetet mellan funktionssystemen grundar sig inte på konsensus, utan på deras ömsesidiga vinster och på komplementaritetsprincipen (Luhmann 1991, Gould 2000).

För att sammanfatta: autopoietiska system är självskapande. De har en egen dynamik, och de reproducerar sig själva. Sociala system äger prioritet i förhållande till individer eller grupper. System kan aldrig påverka eller kommunicera med varandra direkt, bara indirekt. System är både öppna och slutna för omvärlden. Det som tas in tolkas enligt en systemintern logik, med vars hjälp det bildas interna modeller av andra system. Allt detta är möjligt, därför att samhällets "stoff» är mening som reproduceras genom kommunikation. 


\section{Sociala systems kommunikationsmedier}

Det moderna samhällets differentieringsprocess innebär att olika medier för kommunikation utvecklas och institutionaliseras. Det finns två huvudtyper: spridningsmedier ("disseminating media") och symboliskt generaliserade kommunikationsmedier. Tal- och skriftspråk, TV och e-post är exempel på spridningsmedier; vart och ett av dem kan användas för att överföra identisk information. Sådana medier är lämpliga i grupper där kommunikation sker genom interaktion. Språket är naturligtvis det viktigaste spridningsmediet. Språket kodar allt som sägs och skrivs i en ja- och nejversion. Förutom spridningsmedier finns det även andra symboliskt generaliserade kommunikationsmedier (Lee 2000). Kommunikationsmedier förmedlar den mening som ett socialt system använder för att reproducera sig självt.

Differentierade system uppstår genom en avgränsningsprocess, som markerar vad som är en systemets egen angelägenhet och vad som angår omvärlden. Den kod som uppstår avgör hur information från omvärlden kommuniceras inom systemet, vilka budskap som uppfattas som relevanta och vilka som avvisas som irrelevant bakgrundsbuller. Det är genom det specifika kommunikationsmediet och den binära koden som sociala system definierar sig själva, som de skapar självreferens (möjliggör sin autopoietiska reproduktion) och kommunicerar om omvärlden. Eftersom varje system använder egna koder för att reglera sina gränser gentemot omvärlden, har de också en annorlunda omvärld (som delvis kan sammanfalla med andra systems omvärld).
Den främsta villkoret för att en händelse, en fråga eller en process skall kommuniceras inom ett system är att den blir lingvistiskt kodad. Inom respektive funktionssystem måste den därtill tolkas i enlighet med systemets egna exklusiva kod. Det innebär att när en händelse behandlas av ett specifikt system, kan den få en mening som skiljer sig från den som den fått $i$ andra system. Eftersom systemen opererar med skilda kommunikationsmedier och koder, och eftersom dessa koder inte är utbytbara, råder det med andra ord ett i viktiga avseenden oöverbryggbart avstånd mellan funktionssystemen. Det förhållandet kan förklara varför kvoteringslagstiftning aldrig införts i vissa länder och varför den varit verkningslös i länder där den har införts: rättsystemets kod kan inte verka i arbetsmarknadssystemet. Kvoteringslagstiftning är ett arbetsmarknadspolitiskt instrument, som är tänkt att tvinga arbetsgivare att anställa en viss andel människor som är t.ex. funktionshindrade. Men kvoteringslagstiftningen har mötts av motstånd från arbetsgivarhåll, eftersom den bryter mot arbetsmarknadens princip att arbetsgivare anställer den som bäst lämpar sig för arbetet. Operationer i enlighet med kvoteringslagen står i strid med arbetsmarknadssystemets autopoiesis.

Pengar är ekonomins kommunikationsmedium, medan systemets binära kod är betalning/icke-betalning. Betyg är utbildningssystemets medium. Dess kod är godkänd/underkänd. Makt är politikens medium (kod: regering/opposition), rätten är det rättsliga systemets (kod: lagligt/ olagligt), och kunskap är vetenskapens kom- 
munikationsmedium (kod: sann/falsk), för att ta några exempel.

Att omvärlden observeras genom systemets binära kod får flera följder. Varje system skapar sin egen uppfattning om världen. Det sker en differentiering av perspektiv och av möjligheter att hantera skillnader mellan system och omvärld. Det viktiga är vem, dvs. utifrån vilket funktionssystem, man observerar samhället. Mängden av system och följaktligen också av perspektiv skapar oförutsägbarhet, eftersom varje fenomen per definition kan observeras på olika sätt från skilda system.

Olika system begränsar varandra. Den nämnda anti-diskrimineringslagen gäller ej personer som inte uppfyller kravet på stipulerad arbetsförmåga. Den inkräktar alltså inte på arbetsgivarens rätt att anställa den som är mest lämpad för uppgiften, alltså rätten att selektera enligt systemets binära kod: arbetsförmåga/arbetsoförmåga. Den begränsar enbart arbetsmarknadssystemets möjlighet att utesluta arbetsförmögna personer med funktionshinder. Genom det som Luhmann (1997) kallar styrningsprogram kan dock avstånden mellan systemen överbryggas. Lönebidragsprogrammet kan t.ex. överbrygga avståndet mellan arbetsmarknad och politik, skattesystemet kan övervinna skillnaden mellan ekonomi och politik. Dessa kopplingar innebär alltså att olika system anpassas till varandra, utan att deras binära koder förändras och utan att de överger sina specifika perspektiv. Strukturella kopplingar, eller den ömsesidiga begränsningen av systemen, skapar det vi kallar ordningen i samhället.

\section{Arbetsmarknadssystemets selektionskriterier}

Arbetsmarknaden differentierades som system, när arbetet blev en vara som likt andra varor kunde säljas och köpas på en marknad.Dåuppkomocksåkategorin arbetsoförmåga, eller arbetshandikapp. Kategorin arbetsoförmåga är alltså en modern kategori. Differentiering handlar, som nämndes ovan, alltid om en reduktion av komplexitet. Funktionsdifferentiering handlar om en reduktion av komplexitet i förhållande till det sociala systemets omvärld, medan systemintern differentiering sker för att reducera funktionssystemets egen komplexitet. I och med industrialiseringen utvecklades inom det ekonomiska systemet arbetsmarknadssystemet som ett autopoietiskt system. Det var ett svar på kraven från en alltmer expanderande industriproduktion. Arbetsmarknadssystemet utvecklade isin turkopplingar till rättssystemet i form av olika regleringar, eller olika typer av avtal. Differentieringsprocessen innebär dock inte att arbetsmarknadssystemet har avskilt sig från det ekonomiska systemet. Mellan arbetsmarknadssystemet och det ekonomiska systemet bevaras fortfarande en ömsesidig avhängighet, en strukturell koppling. Denna ömsesidiga avhängighet innebär inte att det ekonomiska systemets binära kod och arbetsmarknadssystemets binära kod knyts samman, men att kommunikationens tema mellan dessa två system är densamma, nämligen att betala/icke-betala lön för anställning, kort sagt att anställa eller att inte anställa.

Arbetsmarknadssystemet är ett levande socialt system. Som sådant består det av en dynamisk kedja av händelser. 
Mediet för kommunikation menar jag är anställningsavtal; när jag fortsättningsvis refererar till anställningsavtal avser jag den särskilda form av anställning som lönearbete innebär. Arbetsmarknaden kan då förstås som ett autopoietiskt system (jfr Luhmann 1992). Den differentierades som ett system när anställningsavtal uppkom. Arbetsmarknaden reproducerar sig när nya avtal sluts och avbryts; dessa avtal refererar oupphörligen till tidigare avtal, för att producera (generera) nya anställningsavtal av samma slag. Anställningsavtal är alltså det mest framträdande inslaget i arbetsmarknadssystemet, medan systemets regler är en sekundär företeelse. Anställningsavtalet bekräftar därmed arbetsmarknadssystemets identitet. Arbetsmarknadssystemets dynamik består av anställningsavtal som oupphörligen länkas till andra anställningsavtal, förväntningar och regler.

Arbetsmarknadensspecifikakommunikationsmediumärsåledesanställningsavtal,och dess specifika operationer uppfattas primärt enligt koden arbetsförmåga/arbetsoförmåga. Den binära koden beskriver en i otaliga situationer dagligen upprepad operation. Ett fullfjädrat arbetsmarknadssystem har differentierats, när distinktionen mellan arbetsförmåga och arbetsoförmåga institutionaliserats. Det är uteslutande genom att köpa och sälja arbetskraft till ett bestämt pris som den moderna arbetsmarknaden definierar sig som ett funktionssystem. När anställningsavtal(lönearbete) upphör finns det ingen arbetsmarknad. Anställningsavtal är arbetsmarknadssystemets kommunikationsmedium på samma sätt som makt är kommunikationsmediet för politiken och pengar för det ekonomiska systemet.

\section{Arbetsmarknadssystemets slutenhet}

Som ovan nämnts har varje autopoietiskt system ett högt specialiserat språk och en klar logik. Luhmanns teori om autopoiesis visar att differentierade system utvecklar en egen logik, en egen rationalitet, utan inre sprickor. Denna logik innebär att arbetsmarknadssystemet antingen anställer eller icke-anställer utan att erkänna några spärrar som begränsar denna mekanism; man kan jämföra med fenomen som massarbetslöshet eller exkludering av vissa grupper.

Systemet rekonstruerar informationen om omvärlden utifrån sitt eget synsätt: arbetsförmåga är allt som inte är arbetsoförmåga. Arbetsförmåga är det som är lönsamt för arbetsgivaren. Kunnig, frisk, effektiv och självständig arbetskraft utgör en kostnadseffektiv investering. Personer definieras av arbetsmarknadssystemet som arbetsoförmögna när de inte bedöms vara lönsamma, t.ex. när de inte arbetar effektivt nog eller om de ofta är sjuka. Eller mer generellt: när de inte kan konkurrera på arbetsmarknaden och därmed inte förmår sälja sin arbetskraft till ett visst pris. Definitionen av arbetsförmåga/arbetsoförmåga formuleras på arbetsmarknadens villkor.

Genom att konstruera världen som kontingent, lägger den binära koden grunden för en förbindelse mellan slutenhet och öppenhet. Allt som uppstår kan tillskrivas positivt eller negativt värde. För varje värdering finns det också en möjlighet till motsatt värdering.

Arbetsmarknadssystemets kod arbetsförmåga/arbetsoförmåga ärkonstant, medan kodens innehåll och de krav som är relate- 
rade till den varierar historiskt. Förändringarna av vad som menas med arbetsförmåga/ arbetsoförmåga samvarierar med förändringar i arbetsmarknadssystemets omvärld. Vi måste här särskilja två nivåer, systemets binära kod och de kriterier som definierar dess binära kod, för att kunna se förändringar i systemet (Luhmann 1996).

Den binära koden arbetsförmåga/arbetsoförmåga markerar gränsen mellan arbetsmarknadssystemet och omvärlden. I varje funktionssystemärden binärakoden det viktigaste redskapet för intern integration och extern avgränsning. Denna kod inkluderar/ exkluderar vad som är relevant/irrelevant för systemet. Det omöjliggör en enhetlig beskrivning och förståelse av förhållandet mellan funktionshindrade personer och arbetsmarknaden, eftersom varje system tolkar informationen om arbetsförmåga och arbetshandikapp utifrån sin egen, särskilda kommunikationskod. För varje fråga finns det olika och konkurrerande tolkningar beroende på observatörens utsiktspunkt. Komplexa frågor som arbete åt funktionshindrade personer behandlas parallellt av flera system. Inkludering av funktionshindrade personer på arbetsmarknaden kommuniceras av det rättsliga systemet. Det sker i termer av exkluderingens eventuella laglighet eller olaglighet. Rättssystemet kommunicerar arbetsgivarens beslut att inte anställa en person med funktionshinder, därför att det är ekonomiskt olönsamt, i termer av legalt/illegalt. Det sker utifrån de rättsligt uppställda normerna. Exempel på sådana normer är arbetsgivarens rätt att anställa den arbetskraft som producerar mest med en given lön, funktionshindrade personers rätt att bli bedömda utifrån sina indivi- duella förutsättningar att utföra arbetet eller deras rätt att få arbetsplatsen anpassad efter deras behov. Arbetsmarknadssystemet kommunicerar lagstiftarens krav på icke-diskriminering, eller lika behandling, i termer av kostnadseffektivitet/-ineffektivtet, utifrån de krav på arbetsförmåga systemet självt har ställt upp.

Att autopoietiska system är slutna och autonoma betyder inte att systemteorin postulerar att världen består av isolerade system, av oberoende system som kretsar i sin omvärld. Ett system är alltid beroende av sin respektive omvärld. Som tidigare framhållits kännetecknas de självproducerande systemen av att de avskärmar sig från otaliga influenser från omvärlden och selekterarnågra få relationer.Strukturell kopplingär mekanismen för detta. Den underlättar systemetsvalda relationer med omvärlden, samtidigt som andra relationer inskränks eller utesluts(Rottleuthner 1989, Moe 1996, Jönhill 1997). Funktionssystemens autonomi överbryggas alltså genom att de strukturella kopplingarna etableras. Alla funktionssystem är förbundna med varandra genom sådana kopplingar.

Beroendeförhållandena mellan systemen minskar inte med ökande grad av funktionell differentiering. Tvärtom ökar de. Men systemen kan inte upprätta kommunikation direkt med varandra, då den systemspecifika kommunikationen utgår från de binära koderna.Eftersom varjesocialtsystemfungerar enligt sin egen binära kod och via sitt kommunikationsmedium reagerar på skillnader i omvärlden och tolkar informationen systeminternt, kan inte kommunikation mellan system och omvärld leda till integration. Funktionssystemen kan bara 
"förståı eller använda sina egna distinktioner. För sociala system betyder kommunikation mellan systemen alltså inte att de knyts samman eller går in i varandra. Ett socialt system är högt specialiserat och kan inte ersättas av ett annat system. De kan däremot störa varandra. Olika krav från omvärlden, t.ex. politiska krav på att personer med funktionshinder ska komma in på arbetsmarknaden, kan väljas bort som icke-relevant information. Rättens krav påatt arbetsgivare ska anlägga jämställdhetsaspekter vid anställning av nya arbetstagare eller, förutsatt att kompetensen i övrigt är likvärdig, att de ska ge företräde åt en viss grupp (positiv särbehandling), irriterar arbetsmarknadssystemet; jämför med arbetsrättens krav att undantag görs för dem med längst anställningstid vid uppsägningar.

Ett system kan alltså störa ett annat genom att iaktta dess aktiviteter och strategiskt störa dess funktionssätt. Strukturella kopplingar uppkommer när ett system kämpar för att finna ett sätt att klara av återkommande störningar från omvärlden. Strukturell koppling innebär att sociala system kan kommunicera om ett gemensamt tema (Jönhill 1997).

Distinktionen mellan system och omvärld innebär inte någon normativ värdering. I själva verket är de båda sidorna ömsesidigt beroende av varandra. Arbetsmarknadssystemet är inte irrelevant för det politiska systemet eller omvänt. Utifrån Luhmanns sociologiska systemteori kan vi dock betona att arbetsmarknadssystemet har en betydande autonomi i förhållande till det politiska systemet. Arbetsmarknadssystemet inrättas och reproducerar sig självt autopoietiskt. Dess egen reproduktion är dess högsta prioritet, och dess omvärld (t.ex. organisationer av funktionshindrade personer, lagstiftning, det socialpolitiska systemet) kan inte direkt påverka dess interna operationer. Eftersom koderna ömsesidigt utesluter varandra och inte kan översättas till varandra, kan ingen av dem tala för de andra eller för samhället i dess helhet (Blühdorn 2000).

Ett systemteoriskt synsätt visar hur svårt det är att gripa in och styra sociala system utifrån. Det understryker i stället att förändringar måste komma inifrån. Men inte heller inne i systemet uppkommer förändringar utan vidare, eftersom den verklighet som systemet inte ser är något annat än dess eget betraktelsesätt (Moe 1996). Funktionshindrade personers situation måste erkännas som ett problem på arbetsmarknaden, innan denna kan reagera. För arbetsmarknadssystemet är dock arbetsoförmögna personers situation ett problem för systemets omvärld. Att anställa en mindre effektiv person, alltså en person med arbetsoförmåga, är att göra omvärldens problem till sitt eget. Politiken kan försöka styra arbetsmarknaden, men i ett systemperspektiv kan bara systemet förändra sig självt. Inte ens det starkaste tryck från omvärlden kan påverka arbetsmarknadssystemet annat än om kravet leder till ömsesidig vinning eller komplementaritet; jämför med lönebidragsanställningar. Arbetsmarknadssystemet har t.ex. visat sig framgångsrikt, oberoende av om det respekterar de mänskliga rättigheterna eller inte.

Autopoiesisteorin innebär att inget av de existerande systemen i samhället kan styra ett annat system. Rätten kan inte användas för att ingripa i arbetsmarknadssystemets interna operationer, eftersom rätten opere- 
rar med en annan logik. Det rättsliga språket skiljer sig helt från arbetsmarknadens beräkningar om produktivitet, effektivitet och arbetsförmåga, vilka för arbetsmarknaden konstituerar en tvingande nödvändighet. Från ett systemteoriskt perspektiv är rättslig intervention alltid något problematiskt.

\section{Systemdiskriminering}

En återblick på arbetsmarknadssystemets historia visar att arbetskraftens ställning i förhållande till produktionen har förändrats. Genom att fastställa vilka arbetssökande som är kvalificerade, eller arbetsförmögna, har man kunnat dra en gräns mot andra arbetssökande.

Arbetskraften förväntas uppfylla vissa krav, som dikteras av produktionens innehåll och inriktning. Vi har sett hur arbetsmarknadssystemets behov av kvalificerad arbetskraft bestämmer innehållet i begreppet arbetsförmåga. Vad som konstituerar arbetsförmåga/arbetsoförmåga bestäms av arbetsmarknadssystemet självt, inte utifrån någon faktor i arbetsmarknadssystemets omvärld. Oliver (1991) hävdar att det var arbetsmarknadssystemets förändrade behov, snarare än begränsningar i funktionshindrade personersarbetsförmåga,som ledde till deras exkludering från arbetsmarknaden. Genom att följa de historiska förändringar som arbetsmarknadssystemet genomgick vid industrialismens uppkomst, kan vi förstå hur funktionshindrade personer har marginaliserats eller uteslutits från arbetsmarknaden.

Lönearbetets uppkomst innebar att arbetsmarknadssystemet differentierades som ett autonomt system inom det ekonomiska systemet. Möjligheten att få anställning och därmedlön blev beroende av arbetsgivarens bedömning av personens arbetsförmåga. Historiskt sett leder den ökade differentieringen till ökad exkludering ur allt fler funktionssystem.

När arbetsmarknadssystemet differentierades som ett system, innebar det ökad exkludering av personer med funktionshinder från detta system. Som ett autopoietiskt system förutsätter arbetsmarknaden ett bestämt förhållande till lönearbete: kravet på arbetsförmåga avgör anställning/ icke-anställning. För att kunna försörja sig genom arbete måste individen sälja sin arbetskraft. Inkludering på arbetsmarknaden förutsätter ett anställningsavtal. Innan lönearbetet uppkom var försörjningsförmågan i stället beroende av möjligheten att sälja egna produkter på en marknad. Individens inkludering berodde alltså av dennes förmåga att i egen takt och utifrån sina egna förutsättningar producera varor som efterfrågades på en marknad. Gallringsmekanismen, att kunna försörja sig eller inte genom eget arbete, var därmed inbyggd i arbetsprodukten. När möjligheten att kunna försörja sig förutsätter ett anställningsavtal, flyttas gallringsmekanismen (ett annat ord kunde vara det vi ofta kallar ssystemdiskrimineringı) till marknadens bedömning av individens förmåga.

Arbetsgivarna har nu möjlighet att gallra bland arbetskraften. Det sker genom allt från standardiserade krav på arbetstakt och prestation till personlighetstester med olika krav på arbetsförmåga.

Ser vi det historiskt, framgår därmed att ett funktionshinder hos den arbetssö- 
kande blev ett tecken på begränsad arbetsförmåga (Blomqvist 1990). När arbetsmarknaden konstituerade sig som ett eget funktionssystem, innebar det ett nytt sätt att organisera arbetet på. Det var då som funktionshindrade personers möjligheter till arbete och försörjning dramatiskt minskade. De blev en ny grupp med ett särskilt problem, som politiken åtog sig att lösa.

Jag hävdar alltså att arbetsförmögna åtskiljdes från icke-arbetsförmögna genom industrialismens, arbetsmarknadens och lönearbetets uppkomst. Innan arbetet blev en vara, något som implicerar ett anställningsavtal mellan arbetsgivare och arbetare, gällde ett annat förhållande, nämligen det mellan producenten och en arbetsprodukt, som bjuds ut på en marknad. Det är själva arbetsprodukten, oberoende av om den är tillverkad av en blind, seende, döv eller hörande, och dess värde som leder till en försörjningsmöjlighet.

De handikappade fanns inte som en särskild kategori, innan arbetsmarknadssystemet differentierades. De räknades in bland de fattiga tillsammans med tiggare, krymplingar, blinda, kriminella, vagabonder och prostituerade, bland alla dem som var föremål för de rikas välgörenhet. Gruppen differentieras samtidigt som arbetsmarknadssystemet. Kravet på inkludering av funktionshindrade på arbetsmarknaden ställs i en rad nationella och internationella rättsliga instrument. Idén bakom dessa krav är att alla människor har samma principiella rätt att inkluderas i alla funktionssystem, även arbetsmarknaden. Principen om de funktionshindrades rätt till de olika funktionssystemen har fastslagits i allt från FN:s deklaration om de mänskliga rättighe- terna till våra dagars anti-diskrimineringslagar. Det innebär dock inte att problemen med exkluderingen från arbetsmarknaden är lösta. Det innebär bara att samma påbud om inkludering upprepas gång på gång. Hur skall rättens krav på lika behandling kunna hävdas mot arbetsmarknadssystemets krav på kostnadseffektivitet och arbetsförmåga? Vi kan jämföra med problemet hur rättens krav på god hälso- och sjukvård ska kunna kommuniceras med politikens krav på minskade utgifter och budgetbalans. Som ett självskapande och självreproducerande system kan inte arbetsmarknaden styras med hjälp av anti-diskrimineringslagar eller annan lagstiftning, som avser att integrera personer med funktionshinder på arbetsmarknaden.Dessbinärakod, arbetsförmåga/ arbetsoförmåga, kan inte förenas med rättssystemets binära kod lagligt/olagligt. Överväganden om arbetsförmåga och kostnadseffektivitet kan inte förklaras som lagliga eller olagliga. Lagen kan inte föreskriva normer eller anvisa en handlingsriktning för arbetsmarknadssystemet, lika lite som detta kan föreskriva politikens inriktning. Enligt systemteorin innebär differentiering, vilket framhållits ovan, att olika system orienterar sig utifrån de funktioner som de uppfyller.

Systemdiskriminering brer ut sig genom de krav som arbetsmarknadssystemet baseras på: lönsamhet, snabbhet, kostnadseffektivitet, konkurrens. Mot denna bakgrund ger systemteorin en kritisk och pessimistisk bild av de funktionshindrades möjligheter att komma in på arbetsmarknaden. För att personer med funktionshinder ska bli inkluderade på arbetsmarknaden förutsätts att arbetsmarknadssystemet reviderar sig självt. 
Eftersom det politiska systemet även i perioder då en stor grupp av befolkningen pga strukturomvandlingen intekan inkluderas i arbetsmarknaden odlar föreställningen att alla bör arbeta (antingen formulerat som rättighet eller som skyldighet), blir frågan om tillträdet till arbetsmarknaden ett problem som ska lösas av politiska aktörer och/ eller av individen själv. Men den diskriminering som personer med funktionshinder utsätts för när de försöker komma in på arbetsmarknaden beror i grunden på att denna aldrig kan efterfråga dyrare och mindre effektiv arbetskraft som behöver olika typer av stöd (personlig assistans, lönebidrag, anpassning av arbetsplats), för att kunna arbeta. Arbetsmarknaden efterfrågar i stället den mest produktiva och kvalificerade arbetskraften till det lägsta priset. Vad personer med funktionshinder råkar ut för när de söker sig in på arbetsmarknaden är en systemdiskriminering.

En anti-diskrimineringslag är på sin höjd ett irritationsmoment för arbetsmarknadssystemet.

\section{Litteratur}

Albertsen, Niels \& Diken, Bülent. "What is the Social?? in http://lancs-iee.comp.lancs.ac.uk/ sociology/soc033bd.html

Bausch C. Kenneth. "The Habermas/Luhmann Debate and Subsequent Habermasian Perspectives on Systems Theory" in Systems Research and Behavioral Science. Vol. 14, 315-330. 1997.

Blomqvist, Martha. Hundra år av undantag. Handikappades förhållande till lönearbete. Sociologiska institutionen Uppsala universitet. 1990.

Blühdorn, Ingolfur. "An offer One Might Prefer to Refuse. The Systems Theoretical Legacy of Niklas Luhmann" in European Journal of Social Theory. 2000, 3(3):339-354.

Foucault, Michel. The Birth of the Clinic. An Archaeology of Medical Perception. Vintage Books. New York. 1975.

Gould, Mark. "Book Review to Niklas Luhmann. Observations of Modernity in American Journal of Sociology. 106:252-254. 2000.

Jönhill, Jan Inge. Samhället som system och dess ekologiska omvärld. En studie i Niklas Luhmanns sociologiska systemteori. Sociologiska institutionen, Lunds universitet. Lund Dissertations in Sociology 17. 1997.

King, Michael \& Schütz, Anton. »The Ambitious Modesty of Niklas Luhmann« in Journal of Law and Society. Vol. 21, No. 3, Sept. 1994. pp. 261-287.

Lee, Daniel. „The Society of Society: The Grand Finale of Niklas Luhmann" in Sociological Theory. 18:2. July 2000.

Leydesdorff, Loet. "Luhmann, Habermas and the Theory of Communication" in Systems Research and Behavioral Science. Vol. 17, 273-288. 2000.

Luhmann, Nilkas. „Paradigm lost: On the Ethical Reflection of Morality" speech on the Occation of the Award of the Hegel Prize 1988. in Thesis Eleven. No 29, pp.82-94. 1991.

Luhmann, Nilkas. »The Coding of the Legal System" in State, Law, Economy as Autopoietic Systems. Eds. A. Febbrajo \& G. Teubner. PP. 145-168. Milano. 1992.

Luhmann, Niklas: Social Systems. Stanford University Press. Stanford, Californial995.

Luhmann, Nilkas. "The Sociology of the Moral and Ethics" in International Sociology. Vol. 11(1):27-36. March 1996.

Luhmann, Niklas. "Limits of Steering" in Theory Culture \& Society. Vol. 14(1):37-39. 1997. London SAGE.

Maturana, R.H. \& Varela, J.F. Autopoiesis and Cognotion. The Realisation of the Living. D. Reidel Publishing Company. 1980.

Maturana, R.H. \& Varela, J.F. "Autopoiesis» in M.

Dimitris Michailakis: Hur arbetsmarknadssystemet... 
Zeleny (ed) Autopoiesis. A Theory of Living Organization. pp.21-33. North Holland. 1981.

Michailakis, Dimitris. "Law as an Autopoietic System« in ActaSociologica. No. 38. pp.323-337. 1995.

Michailakis, Dimitris. Studie av arbetsplatsanpassningar med IT-baserade hjälpmedel för funktionshindrade personer. (Institutet För Arbetsmarknadspolitisk Utvärdering, Uppsala. Forskningsrapport 2000:2), 2000.

Mingers, John. "Systems Typologies in the Light of Autopoiesis: A Reconceptualization of Bouldinges Hierarchy, and a Typology of SelfReferential Systems" in Systems Research and Behavioral Science. Vol. 14, 303-313. 1997.

Moe, Sverre. Sociologisk betraktelse. En introduktion till systemteori. Studentlitteratur. Lund. 1996.

Rottleutner,H. „APurifiedSociology of Law:Niklas Luhmann on the Autonomy of the Legal System" in Law and Society Review Vol. 11. No 2, pp.779-797. 1989.

Stattin, M. Yrke, yrkesförändring och utslagning från arbetsmarknaden - en studie av relationen mellan förtidspension och arbetsmarknadsförändring. Doctoral Theses at the Department of Sociology Umeå University. Umeå. 1998.
Stiker, Henri-Jacques. A History of Disability. Ann Arbor. The University of Michigan Press. 1999.

Stone, A. Deborah. The Disabled State. Macmillan. London. 1985.

Teubner, Gunther. Law as an Autopoietic System. The European University Institute Press Series. Blackwell Publishers. Oxford. 1988.

Teubner, Gunther. „Can Social Systems be Viewed as Autopoietic? «inLSEComplexityStudyGroup.MeetingNo.3.18June 1997.http://www.lse.ac.uk/LSE/ COMPLEX/reports/report97june.htm

Thyssen, Ole. „Interview with Professor Niklas Luhmann, Oslo, April, 2, 1995" in Cybernetics \& Human Knowing. A Journal of Second Order Cybernetics \& Cyber-Semiotics. Vol. 3 no. 2 1995.

Vanderstraeten, Raf. "Autopoiesis and Socialization: on Luhmannss Reconceptualization of Communication and Socialization" in British Journal of Sociology. Vol. No. 51 Issue No. 3 (September) 2000 pp.581-598.

Willke, Helmut. „Autopoiesis and Organised Complexity in LSE Complexity Study Group. MeetingNo.3.18June 1997.http://www.lse.ac.uk/LSE/ COMPLEX/reports/report97june.htm

\section{Summary \\ The Labour Market Systemis Uncommunicativeness for Persons with Disabilities}

The purpose of this article is to apply Niklas Luhmanns sociological systems theory in order to illuminate the relationship between disabled persons and the labor market system. Employment contract is proposed as the labor market systemıs communication medium and working ability/working disability as its binary code. On the basis of this code inclusion or exclusion from the system is communicated. Historically can he observed that working ability/working disability has been redefined several times. The tendency although is that it increasingly becomes more demanding to qualify as ablebodied for the labour market system. Autopoietic systems put coherent demands on themselves, they are oriented according to their function and each system observes other systems as its environment. From the labour market system there is no demand for labour which, in order to fill the tasks imposed, need different types of support. 
Labour market demands the most productive, qualified labor for the lowest possible price. Persons with disabilities encounter system discrimination when they are trying to enter the labour market system, a discrimination that no legal regulation can do away with.

Dimitris Michailakis: Hur arbetsmarknadssystemet... 